\title{
GAMBARAN PENGETAHUAN DAN PERILAKU ANAK DALAM MEMELIHARA KESEHATAN GIGI DAN MULUT TERHADAP TERJADINYA KARIES MOLAR SATU PERMANEN PADA MURID KELAS III DAN IV SD NEGERI 067247 JL. BUNGA MALEM VII KELURAHAN LAU CIH KECAMATAN MEDAN TUNTUNGAN
}

\author{
Ngena Ria \\ Jurusan Keperawatan Gigi Poltekkes Kemenkes Medan
}

\begin{abstract}
Abstrak
Penyakit gigi dan mulut merupakan penyakit gigi yang berhubungan langsung dengan perilaku atau kebiasaan untuk memelihara kesehatan gigi dan mulut. Penelitian yang dilakukan adalah penelitian deskriptif dengan metode survey untuk mendapatkan gambaran mengenai pengetahuan dan perilaku anak dalam memelihara kesehatan gigi dan mulut terhadap terjadinya karies molar satu permanen pada murid kelas III dan IV SD Negeri 067247 Jl. Bunga Malem VII Kelurahan Lau Cih Kecamatan Medan Tuntungan. Populasi adalah Murid SD Negeri 067247 Jl. Bunga Malem VII Kelurahan Lau Cih Kecamatan Medan Tuntungan. Sampel dalam penelitian adalah murid kelas III dan IV dengan jumlah 49 orang. Data yang diperlukan dalam penelitian adalah data primer, yaitu data yang didapat melalui kuesioner dan pemeriksaan langsung pada rongga mulut murid kelas III dan IV SD Negeri 067247 Jl. Bunga Malem VII Kelurahan Lau Cih Kecamatan Medan Tuntungan. Pengetahuan murid kelas III dan IV SDNegeri 067247 Jl. Bunga Malem VII Kelurahan Lau Cih Kecamatan Medan Tuntungan dalam memelihara kesehatan gigi dan mulut terhadap terjadinya karies molar satu permanen dengan kriteria baik 34 orang (69\%), kriteria sedang 15 orang (31\%) dan kriteria buruk (0\%). Perilaku murid kelas III dan IV SD Negeri 067247 Jl. Bunga Malem VII Kelurahan Lau Cih Kecamatan Medan Tuntungan dalam memelihara kesehatan gigi dan mulut terhadap terjadinya karies molar satu permanen dengan kriteria baik 43 orang (88\%), kriteria sedang 6 orang (12\%) dan kriteria buruk (0\%). Murid kelas III dan IV yang terkena karies molar satu permanen sebanyak 37 orang $(76 \%)$, sedangkan yang tidak terkena karies molar satu permanen sebanyak 12 orang (24\%).
\end{abstract}

Kata Kunci : Pengetahuan, Perilaku Anak, Karies Molar Satu Permanen

\section{Latar Belakang}

Pembangunan kesehatan diselenggarakan dengan memberikan prioritas kepada upaya peningkatan kesehatan, pencegahan penyakit dengan tidak mengabaikan upaya penyembuhan dan pemulihan kesehatan, termasuk pada anak usia sekolah dasar agar tercapai derajat kesehatan secara optimal. Untuk menunjang upaya kesehatan yang optimal maka upaya dibidang kesehatan gigi perlu mendapat perhatian (Depkes RI, 2000).

Secara umum, seseorang dikatakan sehat tidak hanya meliputi tubuh saja tetapi juga rongga mulut dan gigi geligi. Mulut merupakan suatu tempat yang amat ideal bagi perkembangbiakan bakteri, karena temperatur, kelembaban dan makanan yang cukup tersedia di dalam rongga mulut, terutama karena pada mulut terdapat fisur gigi, sehingga sisa makanan mudah tertinggal dan merupakan makanan yang disukai oleh bakteri.

Karies gigi merupakan suatu penyakit pada jaringan keras gigi, yaitu email, dentin dan sementum yang disebabkan aktivitas jasad renik yang ada dalam suatu karbohidrat yang diragikan.

Proses karies gigi ditandai dengan terjadinya demineralisasi pada jaringan keras gigi, diikuti dengan kerusakan bahan organik gigi, yang akan menyebabkan terjadinya invasi bakteri dan kerusakan pada jaringan pulpa serta penyebaran infeksi pada jaringan periapikal dan menimbulkan rasa nyeri. Sampai sekarang, karies gigi masih merupakan masalah kesehatan baik di negara maju maupun di negara-negara berkembang.

Berdasarkan hasil Survei Kesehatan Rumah Tangga (SKRT, 2001) prevalensi karies gigi umur 10 tahun keatas adalah sebesar 71,2\%.Berdasarkan Survei Kesehatan Rumah Tangga (SKRT,2004), prevalensi karies gigi di Indonesia mencapai 90,05\% dan tergolong lebih tinggi dibandingkan dengan negara berkembang lainnya.

Karies gigi menjadi salah satu bukti tidak terawatnya kondisi gigi dan mulut masyarakat Indonesia. Penyakit gigi dan mulut merupakan penyakit gigi yang berhubungan langsung dengan perilaku atau kebiasaan untuk memelihara kesehatan gigi dan mulut. Peningkatan 
derajat kesehatan yang optimal bagi masyarakat dipengaruhi oleh empat faktor utama, yakni lingkungan, perilaku, pelayanan kesehatan dan keturunan.

Pengetahuan merupakan hasil tahu dari manusia dan terjadi setelah seseorang melakukan penginderaan terhadap suatu objek tertentu. Pengetahuan kebersihan gigi dan mulut meliputi tentang menyikat gigi, makanan yang mempengaruhi kesehatan gigi serta pengetahuan tentang kapan pemeriksaan gigi secara periodik dilakukan.

Anak masih tergantung pada orang dewasa dalam hal menjaga kebersihan dan kesehatan gigi dimana kurangnya pengetahuan anak mengenai kesehatan gigi dibanding orang dewasa, terutama kurangnya pengetahuan orang tua dan anak mengenai pertumbuhan gigi molar satu permanen.

Gigi molar satu permanen merupakan gigi geraham besar yang berfungsi untuk mengunyah, menumbuk dan menggiling makanan, karena gigi molar mempunyai permukaan kunyah yang lebar dengan banyak lekukan-lekukan.

Menurut Penelitian Sri Harini Soemartono (2006) diperoleh bahwa gigi molar satu permanen merupakan gigi yang peka terhadap karies gigi sehingga pada anak sering dijumpai gigi molar satu permanen telah mengalami kerusakan yang cukup berat, karena gigi molar satu permanen selain memiliki pit dan fisur yang dalam, juga merupakan gigi yang tumbuh lebih awal dari gigi yang lain, yaitu pada usia enam tahun. Banyak masyarakat yang berasumsi bahwa gigi molar satu permanen adalah gigi susu yang akan berganti menjadi gigi tetap.

Berdasarkan uraian di atas penulis tertarik untuk meneliti tentang gambaran pengetahuan dan perilaku anak dalam memelihara kesehatan gigi dan mulut terhadap terjadinya karies molar satu permanen pada murid kelas III dan IV SD Negeri 067247 Jl. Bunga Malem VII Kelurahan Lau Cih Kecamatan Medan Tuntungan.

\section{Rumusan Masalah}

Berdasarkan latar belakang masalah di atas, permasalahan yang timbul dalam penelitian ini adalah : Bagaimanakah gambaran pengetahuan dan perilaku anak dalam memelihara kesehatan gigi dan mulut terhadap terjadinya karies molar satu permanen pada murid kelas III dan IV SD Negeri 067247 Jl. Bunga Malem VII Kelurahan Lau Cih Kecamatan Medan Tuntungan

\section{Tujuan Penelitian}

\section{Tujuan Umum}

Untuk mendapatkan gambaran mengenai pengetahuan dan perilaku anak dalam memelihara kesehatan gigi dan mulut terhadap terjadinya karies molar satu permanen pada murid kelas III dan IV SD Negeri 067247 Jl. Bunga Malem VII Kelurahan Lau Cih Kecamatan Medan Tuntungan.

\section{Tujuan Khusus}

1. Untuk mengetahui gambaran pengetahuan anak dalam memelihara kesehatan gigi dan mulut terhadap terjadinya karies molar satu permanen.
2. Untuk mengetahui gambaran sikap anak dalam memelihara kesehatan gigi dan mulut terhadap terjadinya karies molar satu permanen.

3. Untuk mengetahui gambaran tindakan anak dalam memelihara kesehatan gigi dan mulut terhadap terjadinya karies molar satu permanen.

\section{Manfaat Penelitian}

1. Menambah wawasan pengetahuan siswa dalam menerapkan ilmu tentang kesehatan gigi terutama mengenai pengetahuan dan perilaku siswa dalam memelihara kesehatan gigi dan mulut.

2. Hasil penelitian diharapkan sebagai masukan bagi peneliti lain dan sebagai referensi di perpustakaan Jurusan Kesehatan Gigi Politeknik Kesehatan Medan.

3. Untuk menambah wawasan pengetahuan peneliti dalam menerapkan ilmu pengetahuan tentang kesehatan gigi dan mulut.

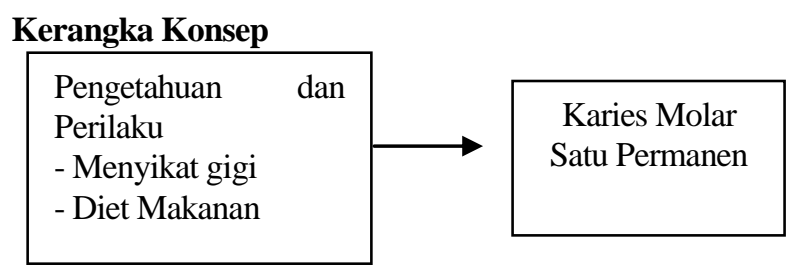

V. Independent $\quad$ V. Dependent

\section{Defenisi Operasional}

Untuk mencapai tujuan yang ingin dicapai dalam penelitian maka penulis menentukan defenisi operasional sebagai berikut :

1. Pengetahuan Anak tentang kesehatan gigi dan mulut adalah pemahaman responden mengenai tingkat pengetahuan tentang kesehatan gigi dan mulut yang digolongkan pada baik, sedang dan buruk yang disesuaikan dengan perhitungan skor jawaban terhadap kuesioner.

2. Perilaku Anak dalam memelihara kesehatan gigi dan mulut terbagi menjadi dua bagian yaitu sikap dan tindakan.

Sikap adalah reaksi atau tanggapan responden terhadap pemeliharaan kesehatan gigi dan mulut yang digolongkan pada baik, sedang dan buruk berdasarkan perhitungan skor kuesioner.

Tindakan adalah anak telah mengetahui kesehatan gigi dan mulut kemudian mengadakan penilaian atau pendapat terhadap pemeliharaan kesehatan gigi dan mulut yang diketahui.

3. Diet makanan adalah jumlah dan jenis makanan (makanan yang baik dan tidak untuk kesehatan gigi dan mulut) yang dikonsumsi oleh responden.

4. Karies gigi adalah penyakit pada jaringan keras gigi yang disebabkan oleh kerja mikroorganisme pada karbohidrat yang dapat diragikan.

5. Molar satu permanen adalah gigi yang berada pada titik ke-6 garis median line dan merupakan gigi yang paling besar, baik pada rahang atas maupun rahang bawah. 


\section{Jenis dan Desain Penelitian}

Jenis penelitian yang dilakukan adalah penelitian deskriptif dengan metode survey, yang bertujuan untuk mengetahui gambaran pengetahuan dan perilaku anak dalam memelihara kesehatan gigi dan mulut terhadap terjadinya karies molar satu permanen pada murid kelas III dan IV SD Negeri 067247 Jalan Bunga Malem VII Kelurahan Lau Cih Kecamatan Medan Tuntungan.

\section{Lokasi Penelitian}

Penelitian dilakukan di SD Negeri 067247 Jalan Bunga Malem VII Kelurahan Lau Cih Kecamatan Medan Tuntungan.

\section{Populasi}

Populasi adalah keseluruhan objek yang diteliti yaitu SD Negeri 067247 Jalan Bunga Malem VII Kelurahan Lau Cih Kecamatan Medan Tuntungan.

\section{Sampel}

Sampel adalah sebagian yang diambil dari keseluruhan objek yang diteliti dan dianggap mewakili seluruh populasi. (Notoatmodjo S, 2002)

Menurut Arikunto S, (2006) apabila subjek penelitian kurang dari 100 maka lebih baik diambil semua, jika subjek lebih besar dari 100 dapat diambil 10-15\% atau 20-25\% atau lebih. Dalam penelitian, sampel penelitian adalah kelas III dan IV dengan jumlah 49 orang.

\section{Jenis dan Cara Pengumpulan Data}

Jenis data yang diambil adalah data primer yang dilakukan dengan menggunakan kuesioner dan pemeriksaan langsung. Data langsung diambil oleh peneliti beserta tim ke lokasi penelitian yaitu SD Negeri 067247 Jalan Bunga Malem Kelurahan Lau Cih Kecamatan Medan Tuntungan. Tim terdiri dari dua orang, dimana kegiatan terdiri dari :

1. Orang pertama, bertugas untuk memanggil sampel satu persatu dan mencatat hasil pemeriksaan.

2. Orang kedua, bertugas untuk memberikan kuesioner dan melakukan pemeriksaan pada sampel.

Adapun data sekunder adalah data yang diperoleh dari dokumentasi seperti, identitas siswa yaitu nama siswa, umur dan kelas.

\section{Analisa Data}

Data yang telah dikumpulkan diolah secara manual, kuesioner yang telah dikumpulkan diperiksa kelengkapan, kejelasan tulisan, ada tidaknya jawaban ganda dan pertanyaan-pertanyaan yang tidak dijawab. Data yang telah diisi siswa-siswi disederhanakan untuk mempermudah pengolahan dengan menggunakan angka atau kode-kode tertentu pada penelitian, yaitu:

- $\quad$ Skor 1 untuk jawaban benar

- $\quad$ Skor 0 untuk jawaban salah

\section{Hasil Penelitian}

Penelitian tentang gambaran pengetahuan dan perilaku anak dalam memelihara kesehatan gigi dan mulut terhadap terjadinya karies molar satu permanen pada murid kelas III dan IV SD Negeri 067247 Jl. Bunga Malem VII Kelurahan Lau Cih Kecamatan Medan Tuntungan, menunjukkan hasil sebagai berikut :

\section{Tingkat Pengetahuan}

Tabel 1 : Distribusi Frekuensi Responden Berdasarkan Tingkat Pengetahuan pada Murid Kelas III dan IV SD Negeri 067247 dalam Memelihara Kesehatan Gigi dan Mulut terhadap Terjadinya Karies Molar Satu Permanen

\begin{tabular}{|l|c|c|}
\hline \multicolumn{1}{|c|}{ Pengetahuan } & $\begin{array}{c}\text { Sampel } \\
(\mathbf{n})\end{array}$ & $\begin{array}{c}\text { Persentase } \\
(\mathbf{\%})\end{array}$ \\
\hline Baik & 34 & 69 \\
\hline Sedang & 15 & 31 \\
\hline Buruk & 0 & 0 \\
\hline Jumlah & 49 & 100 \\
\hline
\end{tabular}

Berdasarkan tabel diatas dapat dilihat bahwa persentase tingkat pengetahuan murid kelas III dan IV SD Negeri 067247 dalam memelihara kesehatan gigi dan mulut terhadap terjadinya karies molar satu permanen dengan kriteria baik sebanyak 34 orang $(69 \%)$, kriteria sedang 15 orang $(31 \%)$ dan kriteria buruk $(0 \%)$.

\section{Persentase Sikap Murid Kelas III dan IV SD Negeri} 067247

Tabel 2: Distribusi Frekuensi Responden Berdasarkan Sikap pada Murid Kelas III dan IV SD Negeri 067247 dalam Memelihara Kesehatan Gigi dan Mulut terhadap Terjadinya Karies Molar Satu Permanen

\begin{tabular}{|l|c|c|}
\hline \multicolumn{1}{|c|}{ Sikap } & $\begin{array}{c}\text { Sampel } \\
(\mathbf{n})\end{array}$ & $\begin{array}{c}\text { Persentase } \\
(\boldsymbol{\%})\end{array}$ \\
\hline Baik & 41 & 84 \\
\hline Sedang & 7 & 14 \\
\hline Buruk & 1 & 2 \\
\hline Jumlah & 49 & 100 \\
\hline
\end{tabular}

Dari tabel diatas dapat dilihat bahwa persentase sikap murid kelas III dan IV SD Negeri 067247 dalam memelihara kesehatan gigi dan mulut terhadap terjadinya karies molar satu permanen dengan kriteria baik adalah sebanyak 41 orang $(84 \%)$, kriteria sedang 7 orang $(14 \%)$, sedangkan kriteria buruk hanya 1 orang $(2 \%)$. 


\subsubsection{Persentase Tindakan Murid Kelas III dan IV SD Negeri 067247}

Tabel 3 : Distribusi Frekuensi Responden Berdasarkan Tindakan pada Murid kelas III dan IV SD Negeri 067247 dalam Memelihara Kesehatan Gigi dan Mulut terhadap Terjadinya Karies Molar Satu Permanen

\begin{tabular}{|l|c|c|}
\hline \multicolumn{1}{|c|}{ Tindakan } & $\begin{array}{c}\text { Sampel } \\
(\mathbf{n})\end{array}$ & $\begin{array}{c}\text { Persentase } \\
(\mathbf{\%})\end{array}$ \\
\hline Baik & 38 & 78 \\
\hline Sedang & 11 & 22 \\
\hline Buruk & 0 & 0 \\
\hline Jumlah & 49 & 100 \\
\hline
\end{tabular}

Berdasarkan tabel diatas dapat dilihat bahwa persentase tindakan murid kelas III dan IV SD Negeri 067247 dalam memelihara kesehatan gigi dan mulut terhadap terjadinya karies molar satu permanen dengan kriteria baik adalah sebanyak 38 orang (78\%), kriteria sedang 11 orang $(22 \%)$ dan tidak ada kriteria buruk $(0 \%)$.

\subsubsection{Persentase Perilaku Murid Kelas III dan IV SD Negeri 067247}

Tabel 4 : Distribusi Frekuensi Responden Berdasarkan Perilaku pada Murid Kelas III dan IV SDNegeri 067247 dalam Memelihara Kesehatan Gigi dan Mulut terhadap Terjadinya Karies Molar Satu Permanen

\begin{tabular}{|l|c|c|}
\hline \multicolumn{1}{|c|}{ Perilaku } & $\begin{array}{c}\text { Sampel } \\
\text { (n) }\end{array}$ & $\begin{array}{c}\text { Persentase } \\
(\boldsymbol{\%})\end{array}$ \\
\hline Baik & 43 & 88 \\
\hline Sedang & 6 & 12 \\
\hline Buruk & 0 & 0 \\
\hline Jumlah & 49 & 100 \\
\hline
\end{tabular}

Dari tabel diatas dapat dilihat bahwa persentase perilaku murid kelas III dan IV SD Negeri 067247 dalam memelihara kesehatan gigi dan mulut terhadap terjadinya karies molar satu permanen dengan kriteria baik adalah sebanyak 43 orang (88\%), kriteria sedang 6 orang (12\%) dan kriteria buruk tidak ada $(0 \%)$.

\subsubsection{Persentase Karies Molar Satu Permanen}

Tabel 5 : Distribusi Frekuensi Responden Berdasarkan Karies Molar Satu Permanen pada Murid Kelas III dan IV SD Negeri 067247

\begin{tabular}{|l|c|c|}
\hline Molar Satu Permanen & $\begin{array}{c}\text { Sampel } \\
(\mathbf{n})\end{array}$ & $\begin{array}{c}\text { Persentase } \\
(\mathbf{\%})\end{array}$ \\
\hline Ada Karies & 37 & 76 \\
\hline Tidak Karies & 12 & 24 \\
\hline Jumlah & 49 & 100 \\
\hline
\end{tabular}

Dari tabel diatas dapat dilihat bahwa jumlah persentase murid kelas III dan IV SD Negeri 067247 yang terkena karies molar satu permanen adalah sebanyak 37 orang $(76 \%)$, sedangkan persentase yang tidak terkena karies molar satu permanen adalah sebanyak 12 orang $(24 \%)$.

\section{Pembahasan}

4.2.1. Distribusi Frekuensi Responden Berdasarkan Tingkat Pengetahuan pada Murid Kelas III dan IV SD Negeri 067247 dalam Memelihara Kesehatan Gigi dan Mulut terhadap Terjadinya Karies Molar Satu Permanen

Berdasarkan tabel 1 dapat dilihat bahwa persentase tingkat pengetahuan pada murid kelas III dan IV SD Negeri 067247 dengan kriteria baik adalah 69\%. Sebagian besar murid $(87,75 \%)$ telah tahu tentang gigi berlubang. Menurut Sriyono W, (2005) bahwa karies gigi merupakan suatu penyakit jaringan keras gigi yaitu email, dentin dan sementum yang disebabkan oleh aktivitas jasad renik dalam suatu karbohidrat yang dapat diragikan. Karies gigi ditandai dengan adanya demineralisasi jaringan keras gigi yang kemudian diikuti oleh kerusakan bahan organik gigi. Akibatnya terjadi invasi bakteri dan kematian pulpa serta penyebaran infeksi pada jaringan periapikal yang dapat menyebabkan rasa nyeri.

Sebagian besar murid $(93,8 \%)$ sudah tahu bahwa pentingnya menyikat gigi dalam memelihara kesehatan gigi dan mulut, meski demikian pada sebagian murid $(6,12 \%)$ belum mengetahui bahwa menyikat gigi sebaiknya pagi sesudah sarapan dan malam sebelum tidur. Menurut Panjaitan M, (1997) menyikat gigi bertujuan untuk memelihara kebersihan dan kesehatan mulut terutama gigi serta jaringan sekitar gigi dan dapat mencegah timbulnya sisa makanan pada sela gigi dan permukaan gigi. Selain menyikat gigi, waktu menyikat gigi harus diperhatikan.

Menyikat gigi dapat menimbulkan rasa segar dalam mulut dan mencegah terjadinya karies gigi dan penyakit perodontal. Menurut Machfoedz (2005) frekuensi menyikat gigi yang baik adalah dua kali sehari yaitu pagi sesudah sarapan dan malam sebelum tidur.

Hanya sebagian kecil murid $(18,36 \%)$ belum mengetahui bahwa pasta gigi yang baik adalah yang mengandung fluor. Menurut Srigupta A, (2004) bahwa pasta gigi menambah cita rasa pada kebiasaan menyikat gigi dan membantu sikat gigi agar lebih mudah bergerak pada permukaan gigi dan dianjurkan menggunakan pasta gigi yang mengandung fluor sesuai dengan kebutuhan.

Hanya sebagian kecil murid (40,8\%) sudah mengetahui bahwa pemeriksaan kesehatan gigi dan mulut sebaiknya dilakukan setiap 6 bulan sekali. Menurut Tarigan R, (1989) setidaknya 6 bulan sekali anak harus dibawa ke dokter gigi untuk memeriksakan kesehatan gigi dan mulut, sehingga gigi yang mulai rusak dapat segera diketahui dan dilakukan tindakan penambalan.

Sebagian besar murid $(59,18 \%)$ belum mengetahui bentuk permukaan bulu sikat gigi yang baik adalah yang datar dan hanya sebagian kecil murid $(20,40 \%)$ tidak tahu bahwa tangkai sikat gigi yang baik digunakan ketika menyikat gigi adalah yang lurus. Menurut Panjaitan, (1995) syarat sikat gigi yang baik adalah tangkai sikat lurus dan mudah dipegang, sehingga dapat mencapai seluruh permukaan gigi dan jaringan 
sekitarnya terutama daerah yang sulit dibersihkan. Kepala sikat harus kecil, bulu sikat harus sama panjangnya dan lembut sehingga membentuk permukaan yang datar, sehingga dapat melakukan pemijatan gusi untuk memperbaiki aliran darah sekitar gusi.

Hanya sebagian kecil murid $(12,24 \%)$ yang tidak mengetahui bahwa makanan yang manis dan lengket kurang baik untuk kesehatan gigi. Menurut Pintauli S, (2008) bahwa faktor substrat dapat mempengaruhi metabolisme bakteri dalam plak dengan menyediakan bahan-bahan yang diperlukan untuk memproduksi asam serta bahan lain yang aktif yang menyebabkan terjadinya karies gigi. Hasil penelitian menunjukkan bahwa orang yang banyak mengkonsumsi karbohidrat terutama sukrosa cenderung mengalami kerusakan pada gigi, sebaliknya pada orang dengan diet yang banyak mengandung lemak dan protein hanya sedikit atau sama sekali tidak mempunyai karies gigi. Hal ini penting untuk menunjukkan bahwa karbohidrat memegang peranan penting dalam proses terjadinya karies gigi.

Hanya sebagian kecil murid $(22,44 \%)$ tidak mengetahui gerakan menyikat gigi yang baik dan benar. Menurut Depkes RI Jakarta (1995), bahwa menyikat seluruh permukaan gigi dengan gerakan maju mundur, selama 2 menit dan sedikitnya 8 kali gerakan untuk setiap permukaan gigi, menyikat permukaan gigi yang menghadap ke pipi dengan cara memutar dan gigi yang menghadap ke bibir disikat dengan gerakan naik turun, serta menyikat gigi dengan gerakan maju mundur pada permukaan gigi bagian pengunyahan.

Menurut Ariningrum R, (2006) kurangnya pengetahuan terhadap kebersihan gigi dan mulut antara lain, tidak mengerti cara menyikat gigi yang baik dan benar, makanan yang menyehatkan gigi dan makanan yang dapat mempengaruhi kebersihan gigi dan mulut.

\subsubsection{Distribusi Frekuensi Responden Berdasarkan Sikap pada Murid Kelas III dan IV SD Negeri 067247 dalam Memelihara Kesehatan Gigi dan Mulut terhadap Terjadinya Karies Molar Satu Permanen}

Dari tabel 2 diperoleh bahwa persentase sikap pada murid kelas III dan IV dalam memelihara kesehatan gigi dan mulut terhadap terjadinya karies molar satu permanen pada umumnya sudah baik yaitu $84 \%$. Secara umum sebagian murid $(93,87 \%)$ setuju bahwa mencegah gigi berlubang sejak memasuki usia sekolah. Menurut Suryanegara R, (2000) memasuki usia sekolah pertumbuhan gigi pada anak harus diperhatikan karena di dalam rongga mulut anak terjadi pertumbuhan gigi campuran (mixed teeth). Hal ini dapat menyebabkan terjadinya gigi berjejal karena kurangnya tempat bagi gigi dan menyebabkan sisa makanan mudah menempel pada gigi sehingga jika anak mengabaikan kebersihan gigi dan mulut dapat menyebabkan terjadinya karies gigi.

Sebagian besar murid $(91,83 \%)$ setuju bahwa sayur dan buah dapat menyehatkan gigi. Sebagian murid $(42,85 \%)$ tidak tahu mengenai makanan yang dapat merusak gigi. Menurut Tarigan R, (1990) bahwa mengurangi makanan yang banyak mengandung gula dapat mencegah terjadinya kerusakan gigi, sebaliknya perbanyak mengkonsumsi makanan yang mengandung serat dan air

Sebagian kecil murid $(6,12 \%)$ tidak setuju bahwa permukaan bulu sikat gigi yang baik adalah yang datar. Menurut American Dental Association (ADA), bahwa bentuk sikat gigi yang baik harus mempunyai kepala sikat kecil, panjangnya 1-1,25 inci dan lebarnya 5/16-3/8 inci dengan 2-4 baris serabut sikat dengan 5-12 bulu sikat, permukaan bulu sikat yang datar/rata dan bulu sikat yang elastis.

Sebagian kecil murid (16,32\%) tidak memiliki sikap untuk mengganti sikat gigi setiap 3 bulan sekali, meski demikian sebagian besar murid $(93,87 \%)$ setuju bahwa menyikat gigi dilakukan dua kali sehari dan sebagian besar murid $(79,59 \%)$ setuju bahwa menyikat gigi sebaiknya pagi sesudah sarapan dan malam sebelum tidur.

Sebagian kecil murid $(14,28 \%)$ tidak memiliki motivasi untuk memeriksakan gigi ke klinik gigi atau membiarkan saja dan sebagian besar murid $(85,71 \%)$ sudah mempunyai motivasi untuk melakukan pemeriksaan gigi setiap 6 bulan sekali. Menurut Pintauli S, (2008) bahwa ada beberapa anjuran pokok yang harus disampaikan kepada masyarakat untuk meningkatkan kesehatan gigi dan mulut yaitu melakukan kebiasaan memelihara kesehatan gigi dan mulut dengan menyikat gigi 2 kali sehari dengan pasta gigi yang mengandung fluor, terutama sesudah sarapan pagi dan malam sebelum tidur, mengganti sikat gigi 2-3 bulan sekali dan mengunjungi dokter gigi secara teratur minimal 2 kali setahun serta memiliki kartu status kesehatan gigi (dental record). Pentingnya kesehatan gigi dan mulut menimbulkan motivasi untuk mendorong sikap kemandirian masyarakat melalui berbagai upaya dan kegiatan untuk meningkatkan kesehatan yang berkesinambungan. Upaya ini tidak saja melibatkan organisasi profesi, tetapi juga melibatkan pihak-pihak lain yang mempunyai kompetensi dan kepentingan yang sama dalam peningkatan dan pencegahan sehingga pada akhirnya dapat tercapai derajat kesehatan gigi dan mulut yang optimal.

\subsubsection{Distribusi Frekuensi Responden Berdasarkan Tindakan pada Murid Kelas III dan IV SD Negeri 067247 dalam Memelihara Kesehatan Gigi dan Mulut terhadap Terjadinya Karies Molar Satu Permanen}

Dari tabel 3 diketahui bahwa persentase tindakan pada murid kelas III dan IV dalam memelihara kesehatan gigi dan mulut terhadap terjadinya karies molar satu permanen secara umum baik yaitu sebesar 78\%. Data hasil penelitian ini diperoleh bahwa sebagian besar murid $(83,67 \%)$ sudah pergi ke dokter gigi bila sedang sakit gigi dan hanya sebagian murid $(8,16 \%)$ belum pergi ke dokter gigi bila giginya berlubang. Menurut Survey Kesehatan Rumah Tangga (SKRT, 1995) dan Survey Kesehatan Nasional (Susenas, 1998) bahwa kesadaran masyarakat untuk datang berobat ke fasilitas pelayanan kesehatan masih rendah. Hal ini terlihat dari $87 \%$ masyarakat yang 
mengeluh sakit gigi tidak berobat, 12,3\% masyarakat yang mengeluh sakit gigi datang berobat ke fasilitas kesehatan gigi sudah dalam keadaan terlambat sehingga dari rata-rata $6,4 \%$ gigi yang rusak $4,4 \%$ gigi sudah dicabut dan $0,7 \%$ mencari pengobatan tradisional.

Masih ada murid (36,73\%) yang belum menyikat gigi selama 2-3 menit. Sebagian besar murid $(91,83 \%)$ sudah menyikat gigi 2 kali sehari. Hanya sebagian kecil murid $(8,16 \%)$ yang tidak meletakkan sikat gigi di dalam gelas atau menggantung sikat gigi dan masih ada murid $(10,20 \%)$ yang tidak menggunakan pasta gigi ketika menyikat gigi.

Menurut Pintauli S, (2008) bahwa menyikat gigi sebaiknya dua kali sehari, menggunakan sikat gigi dengan bulu sikat lunak dan kepala sikat yang kecil sehingga dapat menjangkau semua area di dalam mulut. Penyikatan gigi dilakukan selama dua menit dan disertai dengan penggunaan pasta gigi yang mengandung fluor untuk mencegah karies gigi.

Sebagian besar murid $(53,06 \%)$ masih disuruh oleh orang tua atau keluarga untuk menyikat gigi. Sebagian besar murid $(95,91 \%)$ sudah berusaha menasehati dan membimbing temannya agar tidak malas menyikat gigi. Menurut Depkes (2001), bahwa hanya 77\% masyarakat yang memiliki kebiasaan menyikat gigi dan hanya $10 \%$ diantaranya yang menyikat gigi secara efektif sedangkan 22\% masyarakat Indonesia jarang atau tidak melakukannya. Membersihkan gigi dua kali sehari terutama setelah makan sudah seharusnya menjadi kebiasaan.

Sebagian besar murid $(97,95 \%)$ sudah kumurkumur setelah makan makanan manis dan lengket. Menurut Panjaitan M, (1997) bahwa makanan yang bersifat lunak cenderung memungkinkan terjadinya pembentukan plak daripada makanan yang bersifat keras karena makanan yang lunak lebih mudah melekat pada permukaan gigi. Makanan yang manis merupakan sumber energi bagi bakteri yang hidup dan berkembang biak pada lapisan plak. Pada umumnya makanan yang manis terdapat pada jenis makanan yang mengandung karbohidrat khususnya sukrosa.

\subsubsection{Distribusi Frekuensi Responden Berdasarkan Perilaku pada Murid Kelas III dan IV SD Negeri 067247 dalam Memelihara Kesehatan Gigi dan Mulut terhadap Terjadinya Karies Molar Satu Permanen}

Berdasarkan tabel 4 dapat dilihat bahwa persentase perilaku murid kelas III dan IV dalam memelihara kesehatan gigi dan mulut terhadap terjadinya karies molar satu permanen pada umumnya baik yaitu sebesar $(88 \%)$.

Menurut Notoatmodjo S, (2007) bahwa perilaku yang didasari oleh pengetahuan, kesadaran dan sikap yang positif akan lebih bersifat langgeng (long lasting) daripada perilaku yang tidak didasari oleh pengetahuan.

Menurut Survey Kesehatan Rumah Tangga (SKRT, 1995) dan Survey Kesehatan Nasional (Susenas, 1998) menyatakan bahwa masalah tingginya angka penyakit gigi dan mulut dipengaruhi oleh beberapa faktor antara lain faktor perilaku masyarakat dimana masyarakat belum menyadari pentingnya pemeliharaan kesehatan gigi dan mulut.

\subsubsection{Distribusi Frekuensi Responden Berdasarkan Karies Molar Satu Permanen pada Murid Kelas III dan IV SD Negeri 067247}

Berdasarkan tabel 5 diketahui bahwa persentase murid kelas III dan IV yang terkena karies molar satu permanen adalah sebesar $76 \%$.

Menurut Penelitian Sri Harini Soemartono ( 2006) diperoleh bahwa gigi molar satu permanen merupakan gigi yang peka terhadap karies gigi sehingga pada anak sering dijumpai gigi molar satu permanen telah mengalami kerusakan yang cukup berat, karena gigi molar satu permanen selain memiliki pit dan fisur yang dalam, juga merupakan gigi yang tumbuh lebih awal dari gigi yang lain yaitu pada usia enam tahun. Banyak masyarakat yang berasumsi bahwa gigi molar satu permanen adalah gigi susu yang akan berganti menjadi gigi tetap.

Persentase murid kelas III dan IV yang tidak terkena karies molar satu permanen adalah sebesar $24 \%$. Menurut Afrilina, G (2006) bahwa anak masih tergantung pada orang dewasa dalam menjaga kebersihan dan kesehatan gigi karena kurangnya pengetahuan anak mengenai kesehatan gigi dibanding orang dewasa, terutama kurangnya pengetahuan anak mengenai pertumbuhan gigi molar satu permanen.

Menurut Survey Kesehatan Rumah Tangga (SKRT, 1995) bahwa penyakit gigi dan mulut yang ditemukan pada masyarakat masih berkisar penyakit yang menyerang jaringan keras gigi (karies gigi) dan penyakit jaringan periodontal yang menyatakan bahwa $63 \%$ penduduk Indonesia menderita kerusakan gigi aktif.

\section{Kesimpulan}

Hasil penelitian mengenai gambaran pengetahuan dan perilaku anak dalam memelihara kesehatan gigi dan mulut terhadap terjadinya karies molar satu permanen pada murid kelas III dan IV SD Negeri 067247 Jl.Bunga Malem VII Kelurahan Lau Cih Kecamatan Medan Tuntungan dengan sampel 49 orang adalah :

1. Pengetahuan Murid dalam Memelihara Kesehatan Gigi dan Mulut.

- $\quad$ Kriteria Baik berjumlah 34 orang (69\%)

- Kriteria Sedang berjumlah 15 orang $(31 \%)$

- Tidak ada murid yang berpengetahuan buruk $(0 \%)$

2. Perilaku Murid dalam Memelihara Kesehatan Gigi dan Mulut.

- $\quad$ Kriteria Baik berjumlah 43 orang (88\%)

- $\quad$ Kriteria Sedang berjumlah 6 orang (12\%)

- Tidak ada murid yang berpengetahuan buruk $(0 \%)$

3. Karies Molar Satu Permanen

- $\quad$ Terkena Karies Gigi berjumlah 37 orang (76\%)

- Tidak terkena Karies Gigi berjumlah 12 orang (24\%) 


\section{Saran}

1. Diharapkan peran orang tua dalam mendidik anak untuk memelihara kesehatan gigi dan mulut dengan memperhatikan cara dan waktu menyikat gigi yang baik dan benar, memperhatikan ketersediaan sikat gigi dan pasta gigi yang baik bagi anak, menanamkan dan mengatur pola makan yang baik untuk kesehatan gigi dan mulut serta memperhatikan pertumbuhan dan perkembangan gigi molar satu permanen agar tidak terjadi karies gigi secara dini.

2. Kepada Murid kelas III dan IV SD Negeri 067247 agar membiasakan menyikat gigi dengan baik dan benar serta mengkonsumsi makanan yang baik bagi kesehatan gigi dan mulut.

3. Kepada tenaga kesehatan gigi agar melakukan penyuluhan kepada murid kelas III dan IV mengenai pemeliharaan kesehatan gigi dan mulut terutama gigi molar satu permanen serta menanamkan kebiasaan menyikat gigi yang baik dan benar pada setiap murid.

4. Kepada pihak sekolah hendaknya mengadakan kerja sama dengan Puskesmas untuk kegiatan Usaha Kesehatan Gigi Sekolah (UKGS) supaya dapat dilakukan perawatan kesehatan gigi dan mulut, khususnya terhadap gigi molar satu permanen.

\section{Daftar Pustaka}

Afrilina G, 2006, 75 Masalah Gigi Anak dan Solusinya, PT. Elex Media Komputindo, Jakarta.

Arikunto S, 2006, Prosedur Penelitian Suatu Pendekatan Praktik, PT. Rineka Cipta, Jakarta.

Herijulianti E, dkk, 2002, Pendidikan Kesehatan Gigi, EGC, Jakarta.

Kidd E, dkk, 1992, Dasar-dasar Karies, EGC, Jakarta.

Notoatmodjo S, 2002, Metodologi Penelitian Kesehatan, PT. Rineka Cipta, Jakarta. , 2007, Promosi Kesehatan dan Ilmu Perilaku, PT. Rineka Cipta, Jakarta.

Nuraskin C.A, dkk, 2011, Bahan Ajar Karya Tulis Ilmiah untuk Mahasiswa Jurusan Kesehatan Gigi Medan, USU Press, Medan.
Panjaitan M, 1997,Etiologi Karies Gigi dan Penyakit Jaringan Periodontal, USU Press, Medan.

Pintauli S, 2008, Menuju Gigi dan Mulut Sehat, Pencegahan dan Pemeliharaan, USU Press, Medan.

Politeknik Kesehatan, 2006, Panduan Penyusunan Karya Tulis Ilmiah (KTI), Politeknik Kesehatan, Medan.

Pratiwi D, 2007, Gigi Sehat, Kompas Media, Jakarta.

Srigupta, 2004, Perawatan Gigi dan Mulut, Prestasi Pustaka, Jakarta.

Sriyono W, 2005, Pengantar Ilmu Kedokteran Gigi Pencegahan, Medica UGM, Yogyakarta.

Suryanegara R, 2000, Memperbaiki dan Memperindah Posisi Gigi Anak, Trubus Agriwidya, Bandung.

Tarigan R, 1989, Kesehatan Gigi dan Mulut, EGC, Jakarta.

, 1990, Karies Gigi, Hipokrates, Jakarta.

W.H, Itjiningsih,1995, Anatomi Gigi, EGC, Jakarta. 